\title{
Learning Analytics in 21st century education: a review
}

\author{
Andres Chiappe ${ }^{a}$ \\ Lilian Patricia Rodríguez ${ }^{a}$
}

\section{Abstract}

Learning Analytics is a topic of growing interest among educational research community. As a result of a systematic literature review, this article describes the usefulness of Learning Analytics as a key element to support a proper $21^{\text {st }}$ century education and to intervene its current crisis from the perspective of different educational stakeholders such as teachers, students, principals and family. From a 1384 document corpus, 100 of them were processed through an abstracting and in-depth reading and a further categorizing stage. Results showed that Learning Analytics provides important inputs for a well-informed decision making of educational stakeholders. Also, despite its importance and educational potential, current implementation of Learning Analytics should no longer be restricted to highly technical profiles but to be open to the academic community and the population in general. In that sense, it is proposed that the skills and knowledge related to Learning Analytics must be included in an updated version of " $21^{\text {st }}$ century information literacy".

Keywords: Learning analytics; Big data; MOOC; Learning feedback; Educational quality.

\section{Introduction}

Education is undoubtedly one of the most important structural components of any society and at the same time one that consistently through the years, has been the focus of much justified and almost always quite hard criticism (ARGIBAY; CELORIO; CELORIO, 2014; WESTON; BAIN, 2010). It is well known that today's education is in crisis. Many things are not going well in education today. Such things have to do with diverse educational stakeholders and can be addressed from three major subjects: the first involves students and teachers and the concern about educational quality (TEZANOS, 1995;

\footnotetext{
a Universidad de la Sabana - Colômbia
}

Recebido em: 30 nov. 2016

Aceito em: 06 fev. 2017 
MULFORD, 2006). The second is the absence of the family in the school life of their children (BALLESTA PAGÁN; CEREZO MÁIQUEZ, 2011; PEÑA; DE GUZMÁN PUYA, 2010) and finally the third, focuses on principals and other administrative staff who face the hard task to prepare the current school to meet the challenges and demands of a changing, globalized, competitive and increasingly technological 21 st century (BROCK-UTNE, 2012; FERREIRO, 2006; PÉREZ GÓMEZ, 2010; RUEDA ORTIZ, 2012) which is characterized, among many other things, by producing and using huge amounts of information.

Many classrooms are black boxes even if they have been built in glass. On this classrooms, students see only the information provided by their teachers, teachers see only what their students do while they are in class, and principals and parents really do not know what happens inside the classrooms. This situation makes the task of ensuring continuous improvement in education more difficult.

Besides the above, current education generates a lot of data (ELIAS, 2011) but an educational process developed within a black box does not provide enough information to make better informed decisions and generally this leads to low impact actions and not enough good outcomes (BROOKFIELD, 1995). In this regard, through displaying data generated in classrooms, Learning Analytics, conceived as the process of visualization and interpretation of huge amounts of data (known as Big Data) applied to education (FERGUSON, 2012; LONG; SIEMENS, 2011) offers the possibility to different educational stakeholders to be better informed and thus make better and timely decisions. However, this will not be possible if the skills related to Learning Analytics continue to be restricted to highly technical profiles. Whereas Learning Analytics is an emerging issue in education, a systematic review of literature on the subject is considered useful to identify its key issues and complexities so that it can be incorporated in a critical discourse on the use of ICT in $21^{\text {st }}$ century education.

\section{Review method}

The revision method was designed based on the eight-step proposal of Okoli and Schabram (2010) synthesized in the following sequence of processes, which are shown in Figure 1.

The method was conducted as a set of steps as follows: 


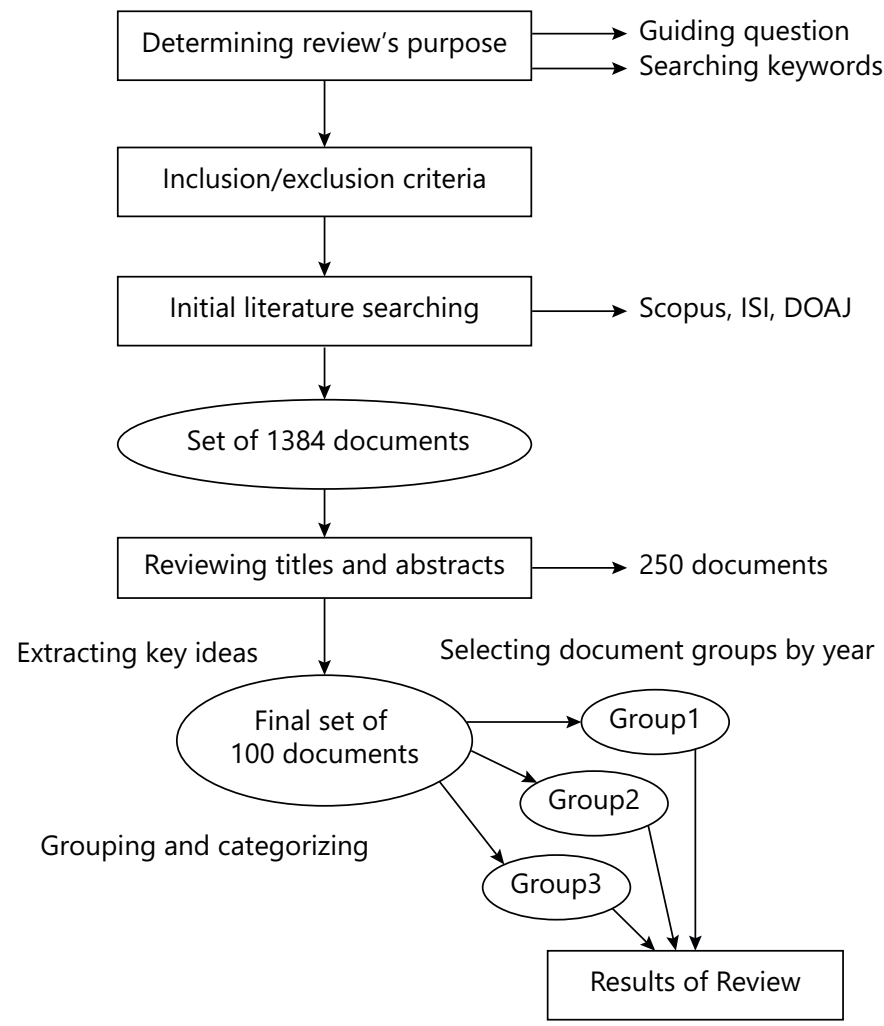

Source: own elaboration (2016).

Figure 1. Review method.

- Determining the review's purpose. In this process a single guiding question was asked as follows: What are the key ideas about Learning Analytics and its relationship with 21 st century education? Then, a single searching keyword was determined as "learning analytics". It should be noted that the relationship between this keyword and the 21 st century education was not addressed from the searching but from the analysis of the selected texts in the in-depth reading process.

- Definition of inclusion/exclusion criteria. After defining the purpose of the review, it was established that the texts to be selected should meet the following requirements: a) present research results, b) explicitly present the searching keyword in either the title or abstract, c) the subject was treated from an educational point of view and d) the text selection should 
represent a weighted percentage of scientific production according to different periods of time.

- Initial literature searching. This process began with the application of the searching keyword in three major peer-reviewed databases: SCOPUS, ISI and DOAJ, and a subsequent filtering by type of document, in which notes, books of an exclusively theoretical nature and editorials were excluded. It was considered appropriate to use these databases as they covered the major high impact factor peer-reviewed journals on education and educational technology, which are the overall context within which learning analytics is addressed as an educational issue.

The search yielded 1384 documents which formed the first set of texts to be analyzed. Figure 2 shows the results of this initial searching with relation to the number of publications per year, indicating the increasing interest, emergence and novelty of this subject in the educational context.

- Abstracting and in-depth reading. From the analysis of the intellectual production graph on Learning Analytics which is shown in this figure, the above mentioned criteria were applied, which allowed to generate a first set of 250 articles. Then, we randomly selected 100 of them with equal representativeness per period of time (as shown in Table 1) which were read in depth, searching for key ideas related to 21 st century education.

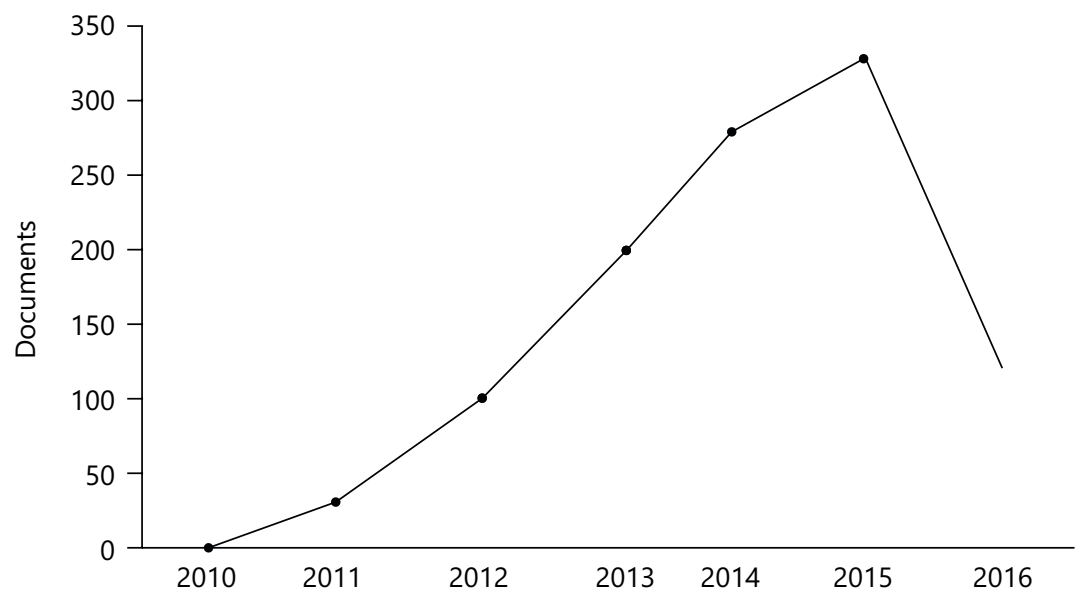

Source: own elaboration based on SCOPUS, ISI and DOAJ data (2016).

Figure 2. Documents by year. 
Table 1. Randomly selection for in-depth reading.

\begin{tabular}{lcc}
\hline Year & Production by year & Randomly selection \\
\hline 2004 & 1 & 1 \\
2010 & 1 & 1 \\
2011 & 31 & 2 \\
2012 & 102 & 7 \\
2013 & 197 & 14 \\
2014 & 293 & 21 \\
2015 & 372 & 26 \\
2016 & 387 & 28 \\
\hline
\end{tabular}

Source: own elaboration based on SCOPUS, ISI and DOAJ data (2016).

- Analysis and interpretation of data. The previously identified key ideas were grouped into various categories and analyzed taking into account their frequency and comparative percentage across categories.

- Discussion of the results. Finally, the data were interpreted taking into account the implications of learning analytics in the context of 21 st century education.

\section{Results}

It is interesting to note that $28,2 \% \%$ of the documents reviewed have been published in the top 30 of the sources consulted. The relevance and reliability of these sources of information is related to the impact factor of the journals and proceedings that have published the documents analyzed, in addition to their quartile location in the JRS, as shown in Table 2.

As a result of the processes of extraction, unification and categorization of data, 21 key ideas were found in three main groups: outdated education, data wastage and popularization. The first category included the following key ideas: quality issues $(62,3 \%)$, decision making $(35,7 \%)$, standardized tests $(28,7 \%)$ and poorly informed stakeholders $(41,4 \%)$. The second included: Internet of things (32,8\%), social networking $(47,4 \%)$, big data (39,8\%), LMS/CMS (23,5\%), ICT (67,9\%), user experiences (20,5\%), MOOC (45,7\%) and Personal Learning Environments (21,9\%). Finally, the third category included: expert systems (34,3\%), platforms and dashboards $(57,9 \%)$, end-user services $(34,2 \%)$, metadata $(40,5 \%)$, statistics $(18,3 \%)$, information literacy $(23,6 \%)$, digital skills $(27,8 \%)$, information society $(24,5 \%)$ and network analysis $(27,8 \%)$.

Figure 3 shows the summary of frequency analysis for the set of key ideas found in this review. 
Table 2. Top 30 sources reviewed.

\begin{tabular}{|c|c|c|c|}
\hline Source name & $\begin{array}{l}\text { SJR impact } \\
\text { factor }\end{array}$ & $\begin{array}{c}\text { SJR } \\
\text { quartile }\end{array}$ & $\begin{array}{c}\text { \% of } \\
\text { documents }\end{array}$ \\
\hline Lecture Notes in Computer Science & 0.252 & Q3 & $7.3 \%$ \\
\hline Computers in Human Behavior & 1,646 & Q1 & $2.5 \%$ \\
\hline $\begin{array}{l}\text { Communications in Computer and Information } \\
\text { Science }\end{array}$ & 0.149 & Q4 & $1.4 \%$ \\
\hline Proceedings - Frontiers in Education Conference, FIE & 0.167 & $\mathrm{~N} / \mathrm{A}$ & $1.2 \%$ \\
\hline $\begin{array}{l}\text { Proceedings of International Conference of the } \\
\text { Learning Sciences, ICLS }\end{array}$ & 0.140 & $\mathrm{~N} / \mathrm{A}$ & $1.1 \%$ \\
\hline Journal of Asynchronous Learning Network & 0.575 & Q2 & $1.0 \%$ \\
\hline Journal of Universal Computer Science & 0.429 & Q2 & $1.0 \%$ \\
\hline British Journal of Educational Technology & 1,613 & Q1 & $0.9 \%$ \\
\hline $\begin{array}{l}\text { International Journal of Technology Enhanced } \\
\text { Learning }\end{array}$ & 0.806 & Q1 & $0.9 \%$ \\
\hline Educational Technology and Society & 1.325 & Q1 & $0.8 \%$ \\
\hline Computers and Education & 3.143 & Q1 & $0.7 \%$ \\
\hline $\begin{array}{l}\text { International Journal of Emerging Technologies in } \\
\text { Learning }\end{array}$ & 0.213 & Q3 & $0.7 \%$ \\
\hline Journal of Computer Assisted Learning & 2.385 & Q1 & $0.7 \%$ \\
\hline Technology, Knowledge and Learning & 0.757 & Q1 & $0.7 \%$ \\
\hline American Behavioral Scientist & 1.007 & Q1 & $0.6 \%$ \\
\hline $\begin{array}{l}\text { Revista Iberoamericana de Tecnologías del } \\
\text { Aprendizaje }\end{array}$ & 0.281 & Q3 & $0.6 \%$ \\
\hline Educational Technology Research and Development & 1.817 & Q1 & $0.6 \%$ \\
\hline $\begin{array}{l}\text { International Review of Research in Open and } \\
\text { Distance Learning }\end{array}$ & 1.352 & Q1 & $0.6 \%$ \\
\hline $\begin{array}{l}\text { Bulletin of the Technical Committee on Learning } \\
\text { Technology }\end{array}$ & 0.170 & Q4 & $0.5 \%$ \\
\hline $\begin{array}{l}\text { IFIP Advances in Information and Communication } \\
\text { Technology }\end{array}$ & 0.160 & Q4 & $0.5 \%$ \\
\hline International Journal of Engineering Education & 0.799 & Q1 & $0.5 \%$ \\
\hline Internet and Higher Education & 3.561 & Q1 & $0.5 \%$ \\
\hline Advances in Intelligent Systems and Computing & 0.153 & Q4 & $0.4 \%$ \\
\hline IEEE Transactions on Learning Technologies & 0.733 & Q1 & $0.4 \%$ \\
\hline TechTrends & 0.467 & Q2 & $0.4 \%$ \\
\hline Interactive Learning Environments & 0.852 & Q1 & $0.3 \%$ \\
\hline $\begin{array}{l}\text { International Journal of Artificial Intelligence in } \\
\text { Education }\end{array}$ & 0.567 & Q2 & $0.3 \%$ \\
\hline Journal of E-Learning and Knowledge Society & 0.166 & Q4 & $0.3 \%$ \\
\hline Journal of the Learning Sciences & 3.364 & Q1 & $0.3 \%$ \\
\hline Education and Information Technologies & 0.528 & Q2 & $0.3 \%$ \\
\hline
\end{tabular}

Source: own elaboration based on SCOPUS, ISI and DOAJ data (2016). 


\section{Frequency of key ideas}

Quality

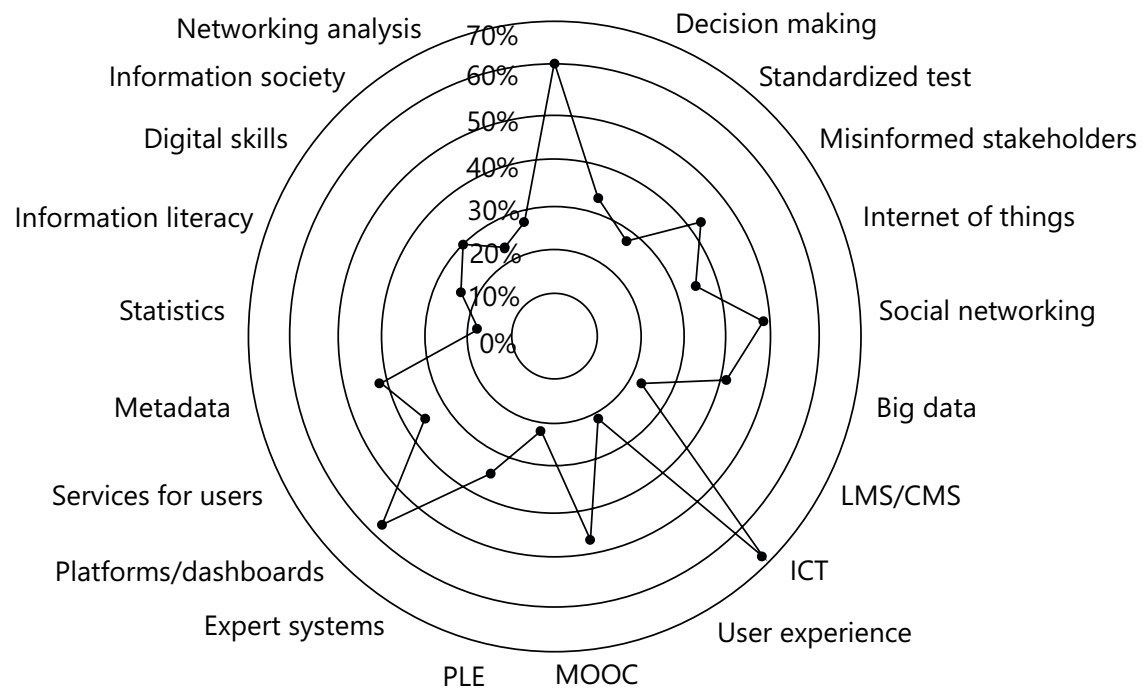

Source: own elaboration (2016).

Figure 3. Frequency of key ideas.

\subsection{Synthesis of results}

Reading in depth of the final set of documents led to the extraction of key ideas related to Learning Analytics and its relationship with $21^{\text {st }}$ century education, which were categorized into three groups, which are presented as follows.

\subsubsection{A new education with old problems}

The academic community is seeing current educational systems critically and a lot of issues are being discussed and analyzed with the aim of consolidating an adequate $21^{\text {st }}$ century school (SHERIDAN; GUTKIN, 2000; WILLIS, 2003). Standardized and global programs like PISA show a disturbing educational landscape worldwide. Regarding its results of 2012, only five of the 65 participant countries reached the high part of the scale in mathematics with a score above 550, only three for sciences and one for reading skills (OECD, 2014). It is noteworthy that more than a half of countries are listed in the middle section of the score and the rest, most of all countries in Latin America and South Asia, sadly lies at the bottom of this measure.

Besides the above, the current school institution is a fairly close reflec tion of which gave rise back to the early nineteenth century (BERNAL, 1993; 
FERNÁNDEZ, 2009; NÓVOA, 2009). At that time, the social context required a way to form new generations to work within a dynamics of increasing industrialization. To achieve its mission, the society of the time structured an intricate orderly school organization that has persisted over the years and has been gradually refined and modernized to show the way schools and universities currently operate. Now, however such modernization, their logic and structure of its origins still persist. In this scenario, the school managers responsible for planning and development processes do not have enough information and often, even if they did, do not know how to interpret it to drive the school development in a way that comes closest to what a 21 st century school should be.

Otherwise, it is well known that Family is a key educational stakeholder. In fact, parents must be the first and main responsible for children's formation and in this sense, one of the major criticisms of the current educational system has to do with the delegation of Family's educational role to the schools (GARCÍA-BACETE, 2003). This situation takes on very complex proportions to analyze due to family's current crisis as a social key institution and because of its surrounded scenario of multiple and diverse conceptions of family and by postmodern and individualistic social imaginaries about it. This, together with the equally diverse socio-cultural conditions of current school, makes Family-School relations a very complex problem to deal with.

Regarding the above, a breakdown of what should be a close relationship between school and family is identified, which has caused a permanent state of parental misinformation (NEUFELD; MATÉ, 2013).

The few opportunities that parents know what is happening with the education of their children are reduced to regular meetings with teachers in which performance or grading reports are delivered, which happens when you have already completed a certain period of school time and the educational process has already been carried out as an accomplished fact.

Three problems of today's education have been presented so far and for each one Learning Analytics has a significant contribution. Although the goal of Education is not improving students' performance on standardized tests such as PISA, their results show many aspects to improve curriculum, teaching and learning, which can be intervened from the analysis of the data produced by each school.

Moreover, a 21st century school which has been achieved structurally implement a process of learning analytics will not only be a more relevant institution for 
the reality of our time but also will allow re-connect Family to School through training of parents in access, visualization and interpretation of data generated by the educational process of their children in real time, so it is possible for parents to make timely decisions and take appropriate actions to correct if necessary or strengthen if desirable.

Regarding quality issues, Learning Analytics was addressed in $73,7 \%$ of the reviewed documents and the main topics provided by those authors were: early predictions $(71,1 \%)$, timely interventions $(69.3 \%)$ and educational decision making (48.2\%)". Examples of the above were found in (BARMAKI; HUGHES, 2015; FULANTELLI; TAIBI; ARRIGO, 2014; KIM, 2012; MAH, 2016; RIENTIES; TOETENEL, 2016). In that sense, it is noteworthy that only a very small fraction of the literature (2\%) addresses analysis of data produced by the student and his relationship with the family, except for homeschooling experiences. Considering the importance of the family in children's education, the above becomes a space with great potential for research.

\subsubsection{Education produces a lot of wasted data: and there will be more}

The pace of today's world change is unpredictable. We have seen during the last decades, rapid changes in many aspects of human life. Most of these changes have been produced by a direct influence of the development and massification of Information and Communication Technologies (ICT). One of the most highlighted trends in this matter is the advent of a very interesting concept: "Internet of things", which will be part of education in the coming years and will produce huge amounts of educational data.

Internet of things (IoT) is defined by Xia et al. (2012) as:

[...] the networked interconnection of everyday objects, which are often equipped with ubiquitous intelligence. IoT will increase the ubiquity of the Internet by integrating every object for interaction via embedded systems, which leads to a highly distributed network of devices communicating with human beings as well as other devices (p. 1101).

In this context, everyday human activities and objects allow people to be interconnected by a constant flow of information in large quantities. In this regard, since the overabundance of information is one of the most distinctive features of our time, this presents special challenges both from curricular and 
teaching dimensions, in terms of priorities and relevance in teaching objects and expectations and interests of student's learning.

According to the above, and considering what a $21^{\text {st }}$ century school should be, this kind of institutions would be part of that flow both as producers and consumers of information. In that sense, it is not a matter of only providing schools with strong Wi-Fi networks and computers or mobile devices through which students and teachers can connect to the Internet, but also of achieving the School, as a whole, produces information potentially useful for educational stakeholders (KORTUEM et al., 2010).

Because things will be interconnected, school tables, chairs, walls, windows and corridors as well as Learning Management Systems and other support tools should provide educationally useful data that reveal what happens inside and outside the classrooms and thereby allow to make better-informed decisions and actions. Moreover, if students develop the skills related with Learning Analytics it would be possible that they, wherever they are (inside or outside the school) may be connected to the library, to learning support systems, to academic networks, to their teachers and their peers, and mainly to information generated by themselves, enabling them to improve their learning experiences. In this sense, we can assume that if all these things happen, the school would undoubtedly will be recognized as a 21 st century school.

As we stated before, 21st century world is characterized by a huge production and an intense use of information. Boorstin (2010) reported on her section "Media Money" on CNBC online a fragment of Google's CEO Eric Schmidt speech at Techonomy Conference 2010 and said: "[ $\ldots$... every two days we create as much data as we created in all history up until 2003. A lot of that data is user generated, and a lot of that comes from people describing enormous amounts of things about themselves." In addition, Marr (2015, p. 69) mentioned that "An estimated of 571 new websites are created every minute of the day".

Considering the mentioned above, it is easy to identify a disagreement between the features of 21 st century world and the current School. While the world moves and transforms in a direction consistent with the development of the "Information Society" (WEBSTER, 2014), education still persists in applying outdated ways to operate.

In this situation, Learning Analytics could play an important updating role for current schools not only making the school to produce and manage enough 
information but to take advantage of this aiming to improve their educational quality. This begins to make sense when you consider that classrooms (face to face, blended or online) will produce highly diverse information that could help teachers to make timely decisions, adjust teaching strategies or get closer to some lost student. Also, this information could help students to strengthen their learning, change learning habits, improve their time management, and finally, it will be useful for principals to make better teacher evaluations, adjust future school planning, training the staff, etc. (DUVAL, 2011).

As the mass production of information is one of the most important elements for learning analytics educational context, this matter is explicitly presented in $83,5 \%$ of the reviewed documents. In that sense, the literature review shows that major issues about that are: Massive Open Online Courses -MOOC- (54,1\%), monitoring m-learning processes $(42,6 \%)$, personal learning environments -PLE- $(38,1 \%)$ and the use of social networking in education $(75,3 \%)$. Examples of the above were found in (MITEVA; NIKOLOVA; STEFANOVA, 2015; RIOFRIO et al., 2015; SOFTIC et al., 2014; WORSLEY et al., 2015).

\subsubsection{Learning analytics must be everybody's business}

Although learning analytics is considered valuable in an era where information is one of the most valuable assets to society, the skills needed to perform it are highly technical (RABELO et al., 2015) and known to a relative few. So, if an ever-increasing production of data is expected in the near future schools, then training students, teachers and school staff in the skills necessary to perform learning analytics will be a key task to accomplish educational improvement.

This may sound great but for this to become reality, Learning Analytics would have to stop being an exclusive concern of people with a highly technical profile and being focused and geared towards expert management of systems and tools. About this, Tan and Wang (2010) said that information is usually captured and analyzed by experts and then making available to the rest of the people in understandable formats or through platforms or dashboards designed for that purpose. This current situation, being the most practical, is not scalable and will need a different and massive approach. In this context, the use of large amounts of information by students, teachers and faculty staff will be possible only if properly developed certain skills, which should be part of an evolved version of what is known as "Information Literacy". Currently, information literacy is focused on searching, selection and use of information from Internet or other networked sources in order to solve a particular problem either in the school, personal or social context (BRUCE, 1999; WEBSTER, 2014). This, in the field 
of learning analytics is quite insufficient, and then it would have to add certain skills for production, visualization and interpretation of data and its subsequent conversion into meaningful information.

Moreover, if Learning Analytics stop being a few expert's issue and becomes to be part of every student and teacher topic of expertise, we will be really starting to educate a whole new generation better prepared to face challenges of Information Society.

Regarding the above, training young people in the management and interpretation of Big Data will allow to be prepared for the demands of the jobs of the future, which will use this kind of information extracted from data interpretation to become more competitive and providing services and more personalized products to the tastes, interests and needs of diverse costumers (CHEN; CHIANG; STOREY, 2012; SAVICKAS et al., 2009).

Now, in addition to considering an economic benefit for both individuals and organizations, the value of training on Learning Analytics is perceived from the perspective of the construction of knowledge (SNIJDERS; MATZAT; REIPS, 2012). If 21 st century has been characterized under the concept of "information and knowledge society " (ANDERSON, 2008; GARRISON, 2011) people become competitive to the extent that not only know how to use the information available but if they are capable of producing useful knowledge for them and for organizations in which they work.

Moreover, from an educational point of view, the incorporation of learning analytics to Information Literacy supposed to be aligned with the importance of being an active player in the production of knowledge, which is a key 21st century education feature (JANG, 2016). In that vein, learning analytics is regarded to be a proper source of knowledge production from the collection, organization, visualization and interpretation of raw data. This takes considerable dimensions if, as mentioned above, data production will increase significantly over the years.

The literature review mentions consistently (69\% of the revised documents) of technical components that require high expertise. The main topics in this category relate to the design and use of platforms (65\%), support and user dashboards $(55,3 \%)$, apps $(47,8 \%)$ and visualization methods related to networked learning $(61,8 \%)$. Examples of the above were found in literature (HARRER, 2015; KHALIL; EBNER, 2015; RAMOS-SOTO et al., 2015; WORSLEY et al., 2015). 


\section{Discussion}

It is clear that the 21 st century school must cease to function within the current model of industrial education in which students are rarely really treated as individual, unique and unrepeatable subjects. More than an emphasis on workers training, the current context requires people educated in a global awareness, with social and ecological sensitivity, capable of navigating and not sinking in a world flooded by information.

One of many ways to achieve this, which is part of the perspective shown in this article, has to do with making current school to respond to the needs of $21^{\text {st }}$ century education by transforming and orienting its academic dynamics and operation based on the principles of learning analytics.

This suggests the importance of conducting research on certain sensitive issues, mainly focused on pedagogy. The 21st century School will not only have to meet the educational requirements of a networked context, but the development of communication skills, teamwork and other "21st century competencies" (SIDDIQ; SCHERER; TONDEUR, 2016). Also, it must take into account the learning analytics as a major design factor for teaching and learning strategies. This means it will be necessary to rethink school's educational foundations and integrate them into instructional design processes so it should be possible to use the data produced by students, its visualization and interpretation -by the students- as part of their own learning and feedback processes. So, conducting future research in this area would provide the necessary knowledge to adjust course development and teacher-training programs on the pedagogical use of learning analytics.

Furthermore, if changes in student's learning activities are to be promoted including data visualization, text mining or other components of learning analytics, another major issue must be deepened through research: theory and practice of an updated version of "information literacy". This version should redefine the basics for training students, teachers and family, via managing, interpretation and taking advantage of the production of data produced from school and their own.

Education we have witnessed in the first decade of the 21 st century does not show substantial changes from what happened in much of the previous century. It is possible that in the near future we begin to see changes from an educational point of view, new methodologies, more flexible and truly more student-centered guidelines, where we seek to develop personal talents instead of achieving standardized learning, all of these based on applying Learning Analytics. 
Being mass production of information and interconnectivity in people's daily lives really a very distinctive feature of 21 st century, if the schools are kept away from production and management of Big Data, they will be moving away from a scenario of competitiveness, which is highly negative for the current educational context, characterized by being highly globalized. But this would not be the most serious consequence. Actually, if 21 st century schools are not linked decisively to the incorporation of learning analytics, young graduates of these institutions will not have a suitable profile to perform successfully in society. 


\section{Learning analytics na educação do século XXI: uma revisão}

\section{Resumo}

Learning Analytics é um tema de crescente interesse entre a comunidade de pesquisa educacional. Como resultado de uma revisão sistemática da literatura, este artigo descreve a utilidade do Learning Analytics como um elemento-chave para apoiar uma educação apropriada do século XXI e para intervir na sua crise atual, na perspectiva de diferentes atores educacionais, tais como professores, alunos, diretores e famílias. A partir de um corpus de 1384 documentos, 100 deles foram eleitos e processados por meio de análise, leitura em profundidade e uma posterior fase de categorização. Os resultados mostraram que Learning Analytics fornece insumos importantes para uma tomada de decisão bem-informada de partes educacionais interessadas. Além disso, apesar de sua importância e do seu potencial educacional, a implementação atual do Learning Analytics não deve mais ser restrita a perfis altamente técnicos, mas aberta à comunidade acadêmica e à população em geral. Nesse sentido, propõe-se que as habilidades e os conhecimentos relacionados ao Learning Analytics sejam incluidos em uma versão atualizada da "alfabetização informacional do século XXI".

Palavras-chave: Learning analytic; Big data; MOOC; Feedback de aprendizagem; Qualidade educacional.

\section{Learning analytics en la educación del siglo 21: una revisión}

\section{Resumen}

Learning Analytics es un tema de gran interés para la comunidad de investigación educativa. Como resultado de una revisión de literatura, este artículo describe su utilidad como un elemento clave para apoyar la educación del siglo 21 y para intervenir su crisis actual desde la perspectiva de varios actores educativos como maestros, estudiantes, directivos y familia. De un corpus de 1384 documentos, 100 de ellos fueron procesados a través de la revisión de abstracts, lectura en profundidad y una etapa de categorización final. Los resultados mostraron que el Learning Analytics proporciona insumos importantes para una toma de decisiones bien informada de los actores educativos. Además, a pesar de su importancia y potencial educativo, su implementación no debe limitarse a perfiles altamente técnicos, sino estar abierto a la comunidad académica y a la población en general. Se propone que las habilidades y los conocimientos relacionados con el Learning Analytics deben incluirse en una versión actualizada de una "alfabetización informacional del siglo 21 ".

Palabras clave: Learning analytics; Big data; MOOC; Realimentación del aprendizaje; Calidad educativa. 


\section{References}

ANDERSON, R. E. Implications of the information and knowledge society for education. In: VOOGT, J.; KNEZEK, G. (Eds.). International handbook of information technology in primary and secondary education. New York: Springer, 2008. p. 5-22.

ARGIBAY, M.; CELORIO, G.; CELORIO, J. Educación para el desarrollo: el espacio olvidado de la cooperación. Bilbao: Hegoa; 2014. (Cuadernos de trabajo Hegoa, vol. 19).

BALLESTA PAGÁN, J.; CEREZO MÁIQUEZ, M. C. Familia y escuela ante la incorporación de las tecnologías de la información y la comunicación. Educación XXI, v. 14, n. 2, p. 133-56, 2011. https://doi.org/10.5944/educxx1.14.2.248

BARMAKI, R.; HUGHES, C. E. Providing real-time feedback for student teachers in a virtual rehearsal environment. . In: ACM INTERNATIONAL CONFERENCE ON MULTIMODAL INTERACTION - ICMI 2015, 2015, Seatle. Proceedings... Seatle: ACM, 2015. p. 531-7.

BERNAL, A. O. Aprendizaje cooperativo: una eficaz aportación de la psicología social a la escuela del siglo XXI. Psicothema, v. 5, Supl., p. 373-91, 1993.

BOORSTIN, J. Google's Eric Schmidt kicks off "Techonomy" Conference. $C N B C, 4$ Aug 2010. Available from: <http://www.cnbc.com/id/38565740>. Acess in: 2016 Oct 20.

BROCK-UTNE, B. Language and inequality: global challenges to education. Compare, v. 42, n. 5, p. 773-93, 2012. https://doi.org/10.1080/03057925.2012.706453

BROOKFIELD, S. The getting of wisdom: what critically reflective teaching is and why it's important. In: . Becoming a critically reflective teacher. San Francisco: Jossey-Bass, 1995. p. 1-28.

BRUCE, C. S. Workplace experiences of information literacy. International Journal of Information Management, v. 19, n. 1, p. 33-47, Feb. 1999. https://doi.org/10.1016/S0268-4012(98)00045-0

CHEN, H.; CHIANG, R. H.; STOREY, V. C. Business intelligence and analytics: from big data to big impact. MIS Quarterly, v. 36, n. 4, p. 1165-88, Dec. 2012. 
DUVAL, E. Attention please!: learning analytics for visualization and recommendation. In: INTERNATIONAL CONFERENCE ON LEARNING ANALYTICS AND KNOWLEDGE, 1., 2011, Banff. Proceedings... Seatle: ACM, 2011.p. 9-17.

ELIAS, T. Learning analytics: the definitions, the processes, and the potential. 2011. Available from: $<$ http://citeseerx.ist.psu.edu/viewdoc/download?doi=10. 1.1.456.7092\&rep=rep1\&type=pdf $>$. Acess in: 2016 Sep 12.

FERREIRO, R. F. El reto de la educación del siglo XXI: la generación N. Apertura, v. 6, n. 5, p. 72-85, Nov. 2006.

FERGUSON, R. Learning analytics: drivers, developments and challenges. International Journal of Technology Enhanced Learning, v. 4, n. 5-6, p. 304-17, 2012. https://doi.org/10.1504/IJTEL.2012.051816

FERNÁNDEZ, J. V. M. La escuela centrada en la comunidad. Un modelo de escuela inclusiva para el siglo XXI. Revista Complutense de Educación, v. 20, n. 1, p. 33-52, 2009.

FULANTELLI, G.; TAIBI, D.; ARRIGO, M. A framework to support educational decision making in mobile learning. Computers in Human Behaviour, v 47, n.3, p. 50-9, Jun. 2014. https://doi.org/10.1016/j.chb.2014.05.045

GARCÍA-BACETE, F.-J. Las relaciones escuela-familia: un reto educativo. Infancia y Aprendizaje, v. 26, n. 4, p. 425-37, 2003. https://doi.org/10.1174/021037003322553824

GARRISON, D. R. E-learning in the 21st century: a framework for research and practice. New York: Taylor \& Francis, 2011.

HARRER, A. A design proposal for learner-centered visualisations of learning analytics in collaborative scenarios. In: INTERNATIONAL CONFERENCE ON ADVANCED LEARNING TECHNOLOGIES - ICALT, 15., 2015, Hualien, Taiwan. Proceedings... Washington, DC: IEEE Computer Society Offices, 2015. p. 208-10.

JANG, H. Identifying 21st century STEM competencies using workplace data. Journal of Science Education and Technology, v. 25, n. 2, p. 284-301, 2016. https://doi.org/10.1007/s10956-015-9593-1 
KHALIL, M.; EBNER, M. A STEM MOOC for school children: what does learning analytics tell us? In: INTERACTIVE COLLABORATIVE LEARNING - ICL 2015, 2015, Florence. Proceedings... Washington, DC: IEEE Computer Society Offices, 2015. p. 1217-21.

KIM, S. J. Critical literacy in East Asia literacy classrooms. Perspectives on Global Development and Technology, v. 11, n. 1, p. 131-44, Mar. 2012. https://doi.org/10.1163/156914912X620789

KORTUEM, G. et al. Smart objects as building blocks for the internet of things. Internet Computing IEEE, v. 14, n. 1, p. 44-51, Jan. 2010. https://doi.org/10.1109/MIC.2009.143

LONG, P. D.; SIEMENS, G. Penetrating the fog: analytics in learning and education. EDUCAUSE Review, v. 46, n. 5, p. 30, 2011. https://doi.org/10.17471/2499-4324/195

MAH, D.-K. Learning analytics and digital badges: potential impact on student retention in higher education. Technology, Knowledge and Learning, v. 21, n. 3, p. 285-305, Oct. 2016. https://doi.org/10.1007/s10758-016-9286-8

MARR, B. Big data: using smart big data, analytics and metrics to make better decisions and improve performance. Cornwall: John Wiley \& Sons, 2015.

MITEVA, D.; NIKOLOVA, N.; STEFANOVA, E. Data analytics support for inquiry based learning. In: INTERNATIONAL CONFERENCE ON INTERACTIVE MOBILE COMMUNICATION TECHNOLOGIES AND LEARNING - IMCL 2015, 2015, Thessaloniki, Greece. Proceedings ... Washington, DC: IEEE Computer Society Offices, 2015. P. 116-20.

MULFORD, B. Liderazgo para mejorar la calidad de la educación secundaria: Algunos desarrollos internacionales. Profesorado, v. 10, n. 1, p. 1-22, Jan. 2006.

NEUFELD, G.; MATÉ, G. Hold on to your kids: why parents need to matter more than peers. Toronto: Vintage Canada, 2013.

NÓVOA, A. Educación 2021: para una historia del futuro. Revista Iberoamericana de Educación, n. 49, p. 181-99, Ene.-Abr. 2009.

OKOLI, C.; SCHABRAM, K. A guide to conducting a systematic literature review of information systems research. Sprouts, v. 10, n. 26, p. 1-51, 2010. 


\section{ORGANISATION FOR ECONOMIC CO-OPERATION AND}

DEVELOPMENT -OECD. PISA 2012 results in focus: what 15-year-olds know and what they can do with what they know. France, 2014. Available from: $<$ http://www.oecd.org/pisa/keyfindings/pisa-2012-results-overview. pdf $>$. Acess in: 2016 Sep 10.

PEÑA, E. B.; DE GUZMÁN PUYA, M. V. P. Desafíos de la familia actual ante la escuela y las tecnologías de información y comunicación. Educatio Siglo XXI, v. 28, n. 1, p. 41-68, 2010.

PÉREZ GÓMEZ, A. I. Aprender a educar: nuevos desafíos para la formación de docentes. Revista Interuniversitaria de Formación del Profesorado, v. 24, n. 2, p. 37-60, Ago. 2010.

RABELO, T. et al. SmartLAK: A big data architecture for supporting learning analytics services. In: FRONTIERS IN EDUCATION CONFERENCE- FIE, 2015, El Paso. Washington, DC: IEEE Computer Society Offices, 2015. p. 1-5.

RAMOS-SOTO, A. et al. Towards textual reporting in learning analytics dashboards. In: INTERNATIONAL CONFERENCE ON ADVANCED LEARNING TECHNOLOGIES - ICALT, 2015, Huailien, Taiwan. Proceedings... Washington, DC: IEEE Computer Society Offices, 2015. p. 260-4.

RIENTIES, B.; TOETENEL, L. The impact of learning design on student behaviour, satisfaction and performance: a cross-institutional comparison across 151 modules. Computers in Human Behavior, v. 60, p. 333-341, July 2016. https://doi.org/10.1016/j.chb.2016.02.074

RIOFRIO, G. et al. Business intelligence applied to learning analytics in student-centered learning processes. In: LATIN AMERICAN COMPUTING CONFERENCE CLEI 2015, 2015, Arequipa, Peru. Washington, DC: IEEE Computer Society Offices, 2015. p. 1-10.

RUEDA ORTIZ, R. Educación y cibercultura en clave subjetiva: retos para re (pensar) la escuela hoy. Revista Educación y Pedagogía, v. 24, n. 62, p. 157-71, ene.-abr. 2012.

SAVICKAS, M. L. et al. Life designing: a paradigm for career construction in the 21st century. Journal of Vocational Behavior, v. 75, n. 3, p. 239-50, Dec. 2009. https://doi.org/10.1016/j.jvb.2009.04.004 
SHERIDAN, S. M.; GUTKIN, T. B. The ecology of school psychology: examining and changing our paradiagm for the 21st century. School Psychology Review, v. 29, n. 4, p. 485, 2000.

SIDDIQ, F.; SCHERER, R.; TONDEUR, J. Teachers' emphasis on developing students' digital information and communication skills (TEDDICS): a new construct in 21 st century education. Computers and Education, v. 92-93, p. 1-14, Jan.-Feb. 2016. https://doi.org/10.1016/j.compedu.2015.10.006

SNIJDERS, C.; MATZAT, U.; REIPS, U.-D. Big data: big gaps of knowledge in the field of internet science. International Journal of Internet Science, v. 7, n. 1, p. 1-5, 2012.

SOFTIC, S. et al. Leveraging learning analytics in a personal learning environment using linked data. Bulletin of the Technical Committee on Learning Technology, v. 16, n. 4, p. 10-3, Dec. 2014.

TAN, L.; WANG, N. Future internet: the internet of things.

In: INTERNATIONAL CONFERENCE ON ADVANCED COMPUTER THEORY AND ENGINEERING - ICACTE, 3., 2010, Chengdu, China. Available from: $<$ http://ieeexplore.ieee.org/xpls/abs_all. jsp?arnumber $=5579543>$. Acess in: 2016 Apr. 9.

TEZANOS, A. La formación de educadores y la calidad de la educación. Revista Educación y Pedagogía, v. 7, n. 14-5, p. 36-65, 1995.

WEBSTER, F. Theories of the information society. 4. ed. New York: Routledge, 2014.

WESTON, M. E.; BAIN, A. The end of techno-critique: The naked truth about 1: 1 laptop initiatives and educational change. The Journal of Technology, Learning and Assessment, v. 9, n. 6, 2010.

WILLIS, P. Foot soldiers of modernity: the dialectics of cultural consumption and the 21st-century school. Harvard Educational Review, v. 73, n. 3, p. 390-415, Sep. 2003. https://doi.org/10.17763/haer.73.3.0w5086336u305184

WORSLEY, M. et al. Exploring behavior representation for learning analytics. In: ACM INTERNATIONAL CONFERENCE ON MULTIMODAL INTERACTION - ICMI 2015, 2015, Seatle. Proceedings... Washington, DC: IEEE Computer Society Offices, 2015. p. 251-8. 
XIA, F. et al. Internet of things. International Journal of Communication Systems, v. 25, n. 9, p. 1101-2, 2012. https://doi.org/10.1002/dac.2417

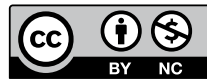

\section{Informação de autores:}

Andres Chiappe: Doctor in Education, Universidad de la Sabana, Colômbia. Researcher at Center of Technologies for Academia. Contato: andres.chiappe@unisabana.edu.co

Lilian Patricia Rodríguez: Doctor in Psychology, Universidad de la Sabana - Colômbia Researcher at Faculty of Psychology. Contato: liliam.rodriguez@unisabana.edu.co 